\title{
PERSEPSI DAN PENDAPAT MASYARAKAT MENGENAI DAMPAK OPERASIONAL TPA SARIMUKI TERHADAP LINGKUNGAN PERAIRAN SEKITAR
}

\author{
Lili Mulyatna*, Anni Rochaeni, Eldiansyah M Thariq \\ Program Studi Teknik Lingkungan, Universitas Pasundan
}

\begin{abstract}
Abstrak
Sampah merupakan hasil sampingan dari berbagai aktifitas dalam kehidupan manusia ataupun sebagai hasil dari suatu proses alamiah yang dapat menimbulkan berbagai pencemaran terhadap lingkungan jika tidak ditangani dengan baik. penelitian ini dilakukan untuk mengetahui sejauh mana tingkat pencemaran air tanah disekitar wilayah TPA (Tempat Pemrosesan Akhir) Sarimukti dan melihat indikasi pencemaran di TPA Sarimukti dan pengaruhnya bagi lingkungan di sekitarnya. Pengujian dilakukan terhadap mata air yang lokasinya berdekatan dengan TPA. Tindakan ini diambil untuk melihat kemungkinan adanya pencemaran air oleh lindi. Pengelola TPA berupaya untuk mengencerkan lindi melalui sungai. Pada TPA Sarimukti limbah lindi dibuang ke anak sungai dan dilakukan 2 kali pengenceran yaitu dari Sungai Cipanauwan dan Sungai Cilimus Hasil uji laboratorium dapat terlihat bahwa pengenceran yang dilakukan efektif, karena hasil pemeriksaan sampel dimana pada saat pencampuran Sungai Cipanauwan dan lindi mengalami peningkatan yang sangat tinggi tetapi dengan 2 kali pengenceran terjadi penurunan yang drastis, hal ini dimungkinkan akibat dari proses pemulihan alami. Telah terkontaminasinya sungai di dekat wilayah TPA akibat dari proses pengenceran air lindi. Pencemaran yang terjadi di Sungai Cipanauwan akibat terjadinya pengenceran dan penyaluran air lindi ke anak sungai disekitar TPA. Belum terjadi pencemaran air tanah terhadap sumber air tanah yang digunakan warga akibat aktifitas TPA Sarimukti. Aktifitas warga juga mempengaruhi tingkat coliform yang berada diatas standar dan hal ini dapat dimaklumi karena Kep Men Kes RI No. 907/Menkes/SK/VII/2002 adalah untuk kualitas air minum, tingkat coliform dapat dikurangi dengan memasak air terlebih dahulu sebelum dikonsumsi.
\end{abstract}

\section{Kata kunci: Lindi, Pencemaran air tanah, Pengenceran, Proses pemulihan alami}

\section{Pendahuluan}

Sampah adalah limbah yang bersifat padat atau setengah padat, yang terdiri dari zat organik dan anorganik, berasal dari hasil kegiatan manusia yang dianggap tidak berguna lagi.

Kesehatan merupakan suatu hal yang sangat penting yang harus dimiliki oleh setiap orang agar mampu berinteraksi sosial dengan

\footnotetext{
${ }^{*}$ Penulis Korespondensi:

E-mail: lili.mulyatna@gmail.com

Diterima pertama kali: 30 Januari 2017

Direvisi : 2 Maret 2017

Disetujui untuk publikasi: 3 Juli 2017
}

lingkungan di sekitarnya. Yang dimaksud kesehatan di sini adalah kesehatan jasmani (fisik) dan kesehatan rohani (jiwa). Namun demikian seseorang belum dapat dinyatakan sehat jika perilaku dan keadaan sosial budayanya tidak sehat, sekalipun ia tidak berpenyakit jiwa dan/ataupun raga.

Beberapa dampak yang mungkin ditimbulkan oleh TPA yang tidak dikelola dengan baik diantaranya pencemaran udara, yakni timbulnya gas-gas yang dihasilkan dari proses pembusukan sampah organik, yaitu gas $\mathrm{H}_{2} \mathrm{~S}$ dan gas Metan yang bersifat racun bagi tubuh (Soemirat, 2002). 
Pencemaran udara lainnya yaitu timbulnya asap dari sampah yang terbakar.

Demikian halnya terhadap air dan tanah, potensi pencemaran terhadap keduanya juga sangat besar. Lindi misalnya, cairan yang dihasilkan dari proses penguraian sampah secara anaerobik ini dapat mencemari tanah, air tanah dan air permukaan (Soemirat, 2002).

TPA di Indonesia masih banyak yang difungsikan dengan jenis open dumping. Sistem ini memiliki potensi tinggi terhadap pencemaran air akibat lindi yang ditimbulkannya (Malita, Ratnawulan, \& Mufit, 2015).

Pencemaran air yang terjadi di sekitar wilayah TPA Sarimukti masih diselidiki, adanya berita tentang air disekitar TPA yang tidak bisa digunakan untuk kebutuhan sehari-hari menjadi poin penting untuk penelitian lebih lanjut.

Atas dasar data tersebut, maka penyusun merasa perlu melakukan penelitian mengenai faktorfaktor yang mempengaruhi kondisi kesehatan warga di sekitar TPA Sarimukti dan sejauh mana tingkat pencemaran air tanah di sekitar wilayah TPA Sarimukti.

Maksud penelitian ini adalah untuk mengetahui sejauh mana tingkat pencemaran air tanah disekitar wilayah TPA Sarimukti. Sedangkan tujuannya adalah melihat indikasi pencemaran di TPA Sarimukti dan pengaruhnya bagi lingkungan di sekitarnya.

\section{Metodologi Penelitian \\ Lokasi Penelitian}

Di wilayah administrasi Desa Sarimukti terdapat TPA yang menampung sampah dari tiga wilayah pemerintahan yaitu Kota Bandung, Kabupaten Bandung dan Kota Cimahi. Lokasi tempat pembuangan akhir sampah tersebut berada di Blok Gedig, Desa Sarimukti, Kecamatan Cipatat. TPA ini beroperasi sejak tahun 2006. Sistem pengelolaan sampah yang diterapkan di TPA Sarimukti adalah sistem open dumping.

\section{Pengumpulan Data}

Pengumpulan data diambil data dilakukan dengan melakukan kuisoner dan mengambil sampel air di sekitar TPA. Pengambilan sampel air dilakukan untuk mengetahui kondisi mata air di sekitar wilayah TPA yang digunakan oleh warga, sample air di sungai terdekat, sumur warga, dan mencari mata air yang digunakan sebagai kontrol dikarenakan tidak adanya data awal tentang sumber air di wilayah sekitar TPA dalam hal ini MCK TPA yang bersumber dari mata air yang berada di atas wilayah TPA

\section{Kuisioner}

Kuisioner dilakukan terhadap warga yang ada di wilayah studi. Dalam hal ini warga yang menjadi responden merupakan sampel dari semua warga (populasi) yang ada di wilayah studi. Metoda sampling yang digunakan adalah sampling acak sederhana dan proporsional.

Langkah-langkah yang dilakukan metode sampling ini adalah sebagai berikut :

1) Menentukan Populasi

2) Penghitungan sampel

3) Pertanyaan Kuisioner

\section{Hasil dan Pembahasan}

\section{Hasil Kuisioner}

Sebagian besar warga di daerah penelitian menggunakan air tanah sebagai sumber air bersih untuk memenuhi kebutuhan sehari-hari (mandi, memasak, mencuci). Berdasarkan hasil kuisioner dari 65 responden, 27 diantaranya $( \pm$ 41,53\%) memakai air tanah (air sumur, baik sumur pompa maupun sumur gali), sedangkan 30 responden $( \pm 46,15 \%)$ memakai mata air sebagai sumber air bersih, $8( \pm 12,30 \%)$ responden memakai sungai sebagai sumber air bersih.

Sebanyak 51 responden $( \pm 78,46 \%)$ menyatakan kualitas fisik air yang digunakan adalah bagus (tidak berwarna, tidak berbau dan tidak berasa), sedangkan 11 responden $( \pm 16,92 \%)$ 
menyatakan jelek dan 3 responden lainnya $( \pm$ 4,61\%) menyatakan tidak tahu. Kualitas air dikatakan jelek karena jika air berbau kadangkadang berasa. Begitu juga yang terjadi pada mata air yang sumbernya berada di dekat TPA kadang-kadang timbul bau yang tidak sedap. Selain itu kualitas air yang jelek juga terjadi karena adanya kontaminasi air limbah rumah tangga. Hal ini umumnya terjadi pada sumursumur yang terletak didekat kolam penampungan air limbah rumah tangga dan sumur-sumur yang terletak di dekat selokan yang menjadi saluran pembuangan limbah. Air sumur yang tercemar tersebut berwarna keruh dan berbau.

Berdasarkan data mengenai mata air, dapat disimpulkan bahwa dari 30 responden ( \pm $46,15 \%$ ) yang memilih mata air, 23 responden $( \pm 35,38 \%)$ menyatakan menyatakan kualitas fisik mata air baik, 7 responden $( \pm 10,76 \%)$ menyatakan kualitas fisik mata air jelek dan tidak ada responden yang tidak tahu.

Mengenai air tanah atau air sumur, dapat disimpulkan bahwa dari 27 responden $( \pm$ 41,53\%) yang memilih air tanah/sumur, 22 responden $( \pm 33,84 \%)$ menyatakan menyatakan kualitas fisik air tanah/sumur bagus, 3 responden $( \pm 4,61 \%)$ menyatakan kualitas fisik air tanah/sumur jelek dan 2 responden $( \pm 3,07 \%)$ menyatakan tidak tahu.

Berdasarkan kuisioner, dapat disimpulkan bahwa dari 8 responden $( \pm 12,30 \%)$ yang memilih sungai, 6 responden $( \pm 9,23 \%)$ menyatakan menyatakan kualitas fisik sungai bagus, 1 responden $( \pm 1,54 \%)$ menyatakan kualitas fisik sungai jelek dan 1 responden $( \pm$ $1,54 \%)$ menyatakan tidak tahu.

\section{Hasil Uji Laboratorium}

Pengujian kualitas air bersih dilakukan untuk melihat sejauh mana kualitas air (terutama kualitas kimia dan biologis) yang selama ini digunakan oleh warga. Pengujian dilakukan terhadap mata air yang lokasinya berdekatan dengan TPA. Tindakan ini diambil untuk melihat kemungkinan adanya pencemaran air sumur oleh lindi. Karena adanya keterbatasan biaya maka dalam penelitian ini pengujian hanya dilakukan terhadap beberapa parameter saja, yaitu warna, kekeruhan, $\mathrm{pH}$, DHL, zat organik, ammonium dan kandungan coliform. Pengujian kualitas air ini dilakukan di laboratorium air jurusan Teknik Lingkungan Universitas Pasundan.

Sampel diambil 2 kali yaitu musim kemarau dan musim hujan. Pengambilan sampel dilakukan 2 kali dikarenakan untuk bahan perbandingan sampel air pada musim hujan dan kemarau.

Sampel yang digunakan dalam penelitian ini berasal dari mata air, sungai, dan sumur timba yang airnya digunakan oleh sebagian besar warga di sekitarnya. Ada 6 sampel yang diperiksa dalam penelitian ini yaitu :

1. Sampel mata air diambil dari TPA MCK/sebagai kontrol, kampung terdekat yang dengan TPA, dan Kantor Desa (menggunakan Kep Men Kes RI No. 907/Menkes/SK/VII/2002 sebagai standar)

2. Sampel air sungai terdekat dari TPA diambil dari Sungai Cipicung dan TPA Sungai Cipanauwan [menggunakan PPRI No. 82 tahun 2001 (Kelas 1)sebagai standar]

3. Sampel air sumur timba diambil dari luar wilayah penelitian yaitu dari wilayah kelurahan Sukaresmi dengan jarak dari TPA $\pm 1500 \mathrm{~m}$, [menggunakan PPRI No. 82 tahun 2001 (Kelas 1)sebagai standar]

Tabel 1 memperlihatkan hasil pemeriksaan sampel air di laboratoirum yang meliputi beberapa parameter. 
Tabel 1. Hasil Uji Kualitas Air Sungai Cipanauwan

\begin{tabular}{|c|c|c|c|c|c|c|c|c|}
\hline \multirow[b]{2}{*}{ No } & \multirow[b]{2}{*}{ Sampel } & \multicolumn{7}{|c|}{ Parameter } \\
\hline & & Warna & Kekeruhan & pH & DHL & $\begin{array}{c}\text { Zat } \\
\text { Organik }\end{array}$ & Amonium & Coliform \\
\hline 1 & $\begin{array}{l}\text { S.Cipanauwan } \\
\text { (Kemarau) }\end{array}$ & 10 & 8 & 6.53 & 553 & 6.72 & 0.05 & 7.3 \\
\hline 2 & $\begin{array}{l}\text { S.Cipanauwan } \\
\text { (Hujan) }\end{array}$ & 2.1 & 3.51 & 7.13 & 613 & 386.5 & 0.64 & 28 \\
\hline 3 & $\begin{array}{l}\text { Air Kampung } \\
\text { (Kemarau) }\end{array}$ & 10 & 9 & 7.7 & 366 & 6.98 & 0.05 & 7.3 \\
\hline 4 & $\begin{array}{l}\text { Air Kampung } \\
\text { (Hujan) }\end{array}$ & 8.25 & 6.2 & 8 & 386 & 51.78 & 0.02 & 3 \\
\hline 5 & $\begin{array}{l}\text { Air Kantor Desa } \\
\text { (Kemarau) }\end{array}$ & 5 & 4.25 & 7.24 & 497 & 6.72 & 0.04 & 7.3 \\
\hline 6 & $\begin{array}{c}\text { Air Kantor Desa } \\
\text { (Hujan) }\end{array}$ & 2.1 & 3.25 & 8 & 470 & 52.97 & 0 & 0 \\
\hline 7 & $\begin{array}{l}\text { Air Sumur } \\
\text { (Kemarau) }\end{array}$ & 40 & 18 & 5.7 & 212 & 8.6 & 0.29 & 11 \\
\hline 8 & Air Sumur (Hujan) & 10.3 & 8.5 & 6.65 & 232 & 52.32 & 3.61 & 7.3 \\
\hline 9 & $\begin{array}{l}\text { S.Cipicung } \\
\text { (Kemarau) }\end{array}$ & 120 & 54 & 7.05 & 1000 & 59.1 & 4 & 75 \\
\hline 10 & S.Cipicung (Hujan) & 25.5 & 10 & 7.42 & 986 & 53.63 & 15.5 & 12 \\
\hline 11 & $\begin{array}{l}\text { Air MCK } \\
\text { (Kemarau) }\end{array}$ & 10 & 4.4 & 7.5 & 404 & 6.45 & 0.05 & 7.3 \\
\hline 12 & Air MCK (Hujan) & 7 & 3.4 & 7.8 & 424 & 51.23 & 0.03 & 3 \\
\hline 13 & Standar & $15^{*}$ & $5^{*}$ & $6-9 * *$ & & $10 *$ & $0,5 * *$ & $100 * *$ \\
\hline 14 & Satuan & $\begin{array}{l}\text { Unit Pt- } \\
\text { Co }\end{array}$ & Unit $\mathrm{SiO} 2$ & - & $\mu \mathrm{m} / \mathrm{cm}$ & $\mathrm{Mg} / \mathrm{l}$ & $\mathrm{Mg} / \mathrm{l}$ & $\mathrm{JPT} / 100 \mathrm{ml}$ \\
\hline & $\begin{array}{l}* \\
* *\end{array}$ & $\begin{array}{l}\text { Men Kes } \\
\text { I No. } 82 \text { to }\end{array}$ & $\begin{array}{l}\text { No. 907/Men } \\
12001 \text { (Kela }\end{array}$ & $\overline{\mathrm{SK} / \mathrm{VI}}$ & & & & \\
\hline
\end{tabular}

Kondisi Sungai Cipanauwan pada saat perbedaan musim terlihat bahwa parameter warna dan kekeruhan mengalami penurunan sedangkan parameter $\mathrm{pH}, \mathrm{DHL}$, Organik, Amonium dan Coliform mengalami kenaikan.

Parameter warna dan kekeruhan mengalami penurunan hal ini dikarenakan tingginya curah hujan, sedangkan parameter $\mathrm{pH}$ berada dalam kondisi netral mengindikasikan bahwa tidak ada perubaan yang signifikan pada sungai cipanauwan dalam perubahan musim. Parameter DHL dan zat organik mengalami peningkatan hal ini menindikasikan naiknya jumlah ion-ion mineral dan zat organik selama musim hujan yang terkandung dalam air Sungai Cipanauwan. Parameter Amonium dan Coliform mengalami peningkatan selama musim hujan hal ini dimungkinkan karena daerah sekitar Sungai Cipanauwan banyak yang dijadikan MCK sementara dan kontur pinggir sungai yang miring memungkinkan untuk terjadinya pencemaran akibat aktifitas MCK pemulung di sekitar TPA. Posisi sungai yang berada disamping TPA sehingga terjadi pencemaran akibat operasional TPA yaitu proses pengenceran lindi yang dilakukan pihak pengelola TPA dengan menyalurkan air lindi ke badan air di sekitar TPA.

Kondisi air dari kampung terdekat memperlihatkan bahwa parameter warna, kekeruhan dan Coliform mengalami penurunan parameter $\mathrm{pH}$, DHL, Organik dan Amonium mengalami kenaikan. 
Parameter warna dan kekeruhan yang mengalami penurunan hal ini di karenakan tingginya curah hujan. Sedangkan untuk coliform disebabkan karena kesadaran warga untuk menggunakan jamban, sedangkan parameter $\mathrm{pH}$ berada dalam kondisi netral dan menindikasikan tidak ada perubaan yang signifikan kondisi air di kampung terdekat dalam perubahan musim. Parameter DHL dan zat organik mengalami peningkatan hal ini dimungkinkan naiknya jumlah ion-ion mineral dan zat organik selama musim hujan yang terkandung dalam air di kampung terdekat. Untuk kampung terdekat kualitas air di kampung tidak terkena dampak langsung dari TPA karena berada di sebelah bukit yang berbeda dengan TPA.

Kondisi air kantor desa terlihat bahwa parameter warna, kekeruhan, $\mathrm{pH}$, DHL, Amonium dan Coliform mengalami penurunan sedangkan parameter zat Organik mengalami kenaikan.

Parameter Zat organik mengalami kenaikan hal ini disebabkan kantor desa dalam proyek rehabilitasi dan penggunaan air pada proyek tersebut menggunakan air kamar mandi kantor desa. Untuk Kantor desa sumber airnya tidak terkena dampak langsung dari TPA karena sumber mata air yang berada di bagian atas TPA.

Pada air sumur warga, parameter warna kekeruhan $\mathrm{pH}$, DHL dan Coliform mengalami penurunan sedangkan parameter Organik, Amonium mengalami kenaikan. Parameter warna, kekeruhan, Parameter DHL dan Coliform mengalami penurunan hal ini dimungkinkan turunnya jumlah ion-ion mineral selama musim hujan yang terkandung dalam air sumur warga mengalami penurunan hal ini dimungkinkan karena kondisi sumur warga tempat pengambilan sampel telah diperkeras baik di dalam maupun di sekeliling sumur dengan semen sehingga memungkinkan berkurangnya rembesan aktifitas MCK warga, sedangkan parameter $\mathrm{pH}$ meningkat dan dalam kondisi netral ini dimungkinkan tidak ada perubaan yang signifikan pada sumur warga dalam perubahan musim. Parameter Amonium dan zat organik dan mengalami peningkatan selama musim hujan hal ini dimungkinkan karena sumur warga yang berada di sekitar persawahan yang memungkinkan air sumur tercemar oleh air tanah yang terkontaminasi penggunaan pupuk. Untuk Sumur warga dimungkinkan tidak terkena dampak langsung dari TPA dikarenakan jarak antara sumur dengan TPA sekitar 1.5 KM dan wilayahnya berbeda dengan TPA Sarimukti.

Kualitas air Sungai Cipicung untuk parameter warna, kekeruhan, $\mathrm{pH}$, DHL, Organik dan Coliform mengalami penurunan sedangkan parameter Amonium mengalami kenaikan. Parameter warna, kekeruhan, pH, DHL, Organik dan Coliform tingginya curah hujan di sekitar sungai Cipicung hal ini menyebabkan tingginya tingkat pengenceran dan memungkinan untuk pemulihan alami sungai Cipicung. Parameter Amonium mengalami kenaikan hal ini disebabkan kondisi sungai bersebelahan dengan sawah warga yang berada dalam posisi lebih tinggi dari sungai Cipicung memungkinkan air dari sawah warga untuk mengalir ke sungai Cipicung.

Untuk Sungai Cipicung terkena dampak langsung dari operasional TPA dikarenakan lindi yang di hasilkan dialirkan ke sungai. Pengelola TPA berupaya untuk mengencerkan lindi melalui sungai ini.

Kondisi Air di MCK TPA yang dijadikan kontrol pada saat perbedaan musim terlihat bahwa parameter warna, kekeruhan, Amonium dan Coliform mengalami penurunan sedangkan parameter $\mathrm{pH}$, DHL, Organik mengalami kenaikan.

Parameter warna, kekeruhan Amonium dan Coliform mengalami penurunan hal ini dimungkinkan karena aktifitas pemulung di sekitar sumber mata air untuk MCK berkurang, 
sedangkan parameter $\mathrm{pH}$ berada dalam kondisi netral dan mengindikasikan tidak ada perubaan yang signifikan pada sungai cipanauwan dalam perubahan musim. Parameter DHL dan zat organik mengalami peningkatan hal ini dimungkinkan naiknya jumlah ion-ion mineral dan zat organik selama musim hujan karena tingginya curah hujan di sekitar mata air. TPA MCK dijadikan kontrol dikarenakan posisinya yang berada di bagian atas TPA sehingga tidak terpengaruh langsung dari aktifitas di TPA Sarimukti.

Pada musim kemarau beberapa parameter Sungai Cipanauwan berada diatas nilai kontrol yaitu kekeruhan, DHL, Zat organik dan $\mathrm{pH}$ hal ini disebabkan pada saat musim kemarau sungai cipanauwan banyak digunakan oleh pemulung. Sedangkan parameter warna, coliform dan amonium nilainya sama. Pada musim hujan parameter kekeruhan, DHL, Zat organik, $\mathrm{pH}$, coliform dan amonium berada diatas kontrol hal ini disebabkan tingginya curah hujan disekitar TPA, sedangkan parameter warna lebih kecil dibandingkan kontrol.

Pada musim kemarau beberapa parameter mata air di kampung terdekat berada diatas nilai kontrol yaitu kekeruhan, DHL, Zat organik ,coliform, amonium dan $\mathrm{pH}$, hal ini disebabkan tingginya tingkat pemakaian air oleh warga. Sedangkan warna, nilainya sama. Pada musim hujan parameter warna, kekeruhan, $\mathrm{pH}$ dan Zat organik berada diatas kontrol, hal ini disebabkan oleh tingginya curah hujan disekitar sumber mata air. Sedangkan parameter DHL, dan amonium lebih kecil dibandingkan kontrol. Untuk parameter coliform nilainya sama.

Pada musim kemarau beberapa parameter kualitas air di kantor desa berada diatas nilai kontrol yaitu $\mathrm{pH}$, DHL, Zat organik dan amonium, hal ini disebabkan sumer air dari kantor desa juag dipergunakan penduduk untuk air kebutuhan sehari-hari. Sedangkan warna dan kekeruhan nilainya dibawah kontrol. Untuk parameter coliform nilainya sama. Pada musim hujan parameter $\mathrm{pH}$, DHL dan Zat organik berada diatas kontrol hal ini disebabkna tingginya curah hujan disekitar sumber air untuk kantor desa. Sedangkan parameter warna, kekeruhan, amonium dan coliform nilainya lebih kecil dibandingkan kontrol.

Pada musim kemarau beberapa parameter kualitas air di sumur warga berada diatas nilai kontrol yaitu $\mathrm{pH}$, warna, kekeruhan, Zat organik, amonium dan coliform hal ini disebabkna tingginya pemakaian air warga dan dinding sumur warga yang belum diplester. Sedangkan DHL nilainya dibawah kontrol. Pada musim hujan parameter DHL, warna, kekeruhan, amonium, coliform dan Zat organik berada diatas kontrol dikarenakan tingginya curah hujan disekitar TPA. Sedangkan parameter $\mathrm{pH}$ nilainya lebih kecil dibandingkan kontrol tetapi masih didalam kisaran $\mathrm{pH}$ netral.

Pada musim kemarau beberapa parameter kualitas air di Sungai Cipicung berada diatas nilai kontrol yaitu DHL, warna, kekeruhan, Zat organik, amonium dan coliform, hal ini disebabkan pengenceran yang dilakukan oleh pihak pengelola TPA ke badan air. Sedangkan $\mathrm{pH}$ nilainya lebih kecil dibandingkan kontrol tetapi masih didalam kisaran $\mathrm{pH}$ netral. Pada musim hujan parameter DHL, warna, kekeruhan, amonium, coliform dan Zat organik berada diatas kontrol, hal ini disebabkan karena tingkat pengenceran lindi yang tinggi dan tingginya curah hujan. Sedangkan parameter $\mathrm{pH}$ nilainya lebih kecil dibandingkan kontrol tetapi masih didalam kisaran $\mathrm{pH}$ netral.

Dari Tabel 1 dapat terlihat beberapa parameter berada di atas standar dalam hal ini berdasarkan Kep Men Kes RI No. 907/Menkes/SK/VII/2002 dan PPRI No. 82 tahun 2001(kelas satu) hal ini dapat dimaklumi dikarenakan Kep Men dan PPRI tersebut berisi tentang syarat-syarat pengawasan kualitas air minum dan peruntukan yang digunakan sebagai air baku air minum, 
untuk beberapa parameter yang berada diatas standar diperlukan pengolahan terlebih dahulu sebelum di konsumsi, yaitu dimasak terlebih dahulu.

Kondisi lingkungan mata air mungkin tercemar akibat aktifitas penduduk sekitar mata air dan bakteri coliform pada air mengindikasikan bahwa pada air tersebut terdapat bakteri patogen, ada beberapa kemungkinan yang menyebabkan tingginya kandungan bakteri coliform dalam air minum, diantaranya : terjadinya kontaminasi oleh pencemaran air lindi. Dalam hal ini kontaminasi air sumur penduduk dimungkinkan oleh kotoran hewan dan tinja manusia tidak terjadi secara langsung melainkan karena adanya rembesan dari kamar mandi penduduk yang berada di sebelah sumur dan kotoran hewan (feses dan urin) serta limbah rumah tangga/air kotor yang meresap kedalam tanah yang pada akhirnya mencemari air sumur. Mengingat di lokasi pengambilan sampel sumur penduduk terdapat kamar mandi dan kandang ternak yang masing-masing berjarak \pm 1 dan 4 meter dari sumur, maka 2 hal tersebut memiliki potensi yang cukup besar sebagai penyebab tingginya kandungan bakteri coliform dalam air sumur tersebut. Adapun pencemaran air yang disebabkan oleh lindi kemungkinannya sangat besar untuk titik sampel sungai cipanauwan, karena longsoran TPA yang pernah terjadi.

Namun demikian kandungan bakteri coliform belum tentu sepenuhnya disebabkan kontaminasi air bersih oleh kotoran hewan dan tinja manusia maupun adanya kontaminasi air sampah, karena selain berasal dari kotoran hewan dan manusia bakteri coliform juga mampu hidup bebas dan dapat berkembang biak dalam air sekalipun secara terbatas.

Pada TPA Sarimukti limbah lindi dibuang ke anak sungai dan dilakukan 2 kali pengenceran yaitu dari Sungai Cipanauwan dan Sungai Cilimus. Hasil uji laboratorium dapat terlihat bahwa pengenceran yang dilakukan efektif, karena hasil pemeriksaan sampel dimana pada saat pencampuran Sungai Cipanauwan dan lindi mengalami peningkatan yang sangat tinggi tetapi dengan 2 kali pengenceran terjadi penurunan yang drastis, hal ini dimungkinkan akibat dari proses pemulihan alami (Christensen et al.,2001) walaupun untuk beberapa sampel berada diatas standar dari Kep Men Kes RI No. 907/Menkes/SK/VII/2002 dan PPRI No. 82 tahun 2001(kelas satu). Akibat operasional TPA Sarimukti terjadi kontaminasi terhadap badan air disekitar TPA tetapi tingkat kontaminasi yang tidak terlalu tinggi hal ini sehingga belum menyebabkan pencemaran hal ini dimungkinkan karena masa operasional TPA Sarimukti yang baru berjalan selama 1,5 tahun tetapi ini juga mengindikasikan bahwa akan terjadi pencemaran apabila akumulasi di anak sungai yang dilewati oleh lindi kalau hal ini tidak ditanggulangi secepatnya akan mengganggu lingkungan dan kehidupan masyarakat sekitar.

Pada musim hujan diambil sampel lagi yaitu untuk mengetahui efektif tidaknya pengenceran yang direncanakan oleh pihak pengelola TPA yaitu dengan memasukkan lindi ke badan air.

\section{Kesimpulan}

Dari hasil pengamatan di lapangan, kuisoner dan uji laboratoriumdisimpulkan bahwa :

1. Telah terkontaminasinya sungai di dekat wilayah TPA akibat dari proses pengenceran air lindi.

2. Pencemaran yang terjadi di Sungai Cipanauwan akibat terjadinya pengenceran dan penyaluran air lindi ke anak sungai disekitar TPA.

3. Pencemaran Sungai Cipanauwan memicu terjadinya pencemaran di Sungai Cipicung dan mungkin akan terjadi akumulasi di sungai Cimeta dan dapat berakibat terjadi pencemaran di Waduk Cirata apa bila tidak tertangani dengan baik. 
4. Belum terjadi pencemaran air tanah terhadap sumber air tanah yang digunakan warga akibat aktifitas TPA Sarimukti

5. Aktifitas warga juga mempengaruhi tingkat coliform yang berada diatas standar dan hal ini dapat dimaklumi karena Kep Men Kes RI No. 907/Menkes/SK/VII/2002 dan PPRI No. 82 tahun 2001(kelas satu) peruntukannya sebagai air baku air minum, tingkat coliform dapat dikurangi dengan memasak air terlebih dahulu sebelum dikonsumsi.

\section{Daftar Pustaka}

Malita, Y. A., Ratnawulan, \& Mufit, F. (2015). Karakterisasi Mineral Magnetik Lindi (Leachate) TPA Air Dingin Kota Padang Menggunakan Scanning Electron Microscopice (SEM). Pillar of Physics, Vol. 5 , 81-88.

Soemirat, J. (2002). Kesehatan Lingkungan. Yogyakarta: Gadjahmada University Press. 